\title{
Synthesis of $\mathrm{LaCrO}_{3}$ Under Hydrothermal Conditions
}

\author{
Masahiro YOSHIMURA, Shen-tai SONG* and Shigeyuki SŌMIYA \\ Laboratory for Hydrothermal Syntheses, Research Laboratory of Engineering Materials and \\ (Department of Materials Science and Engineering, Tokyo Institute of Technology \\ 4259, Nagatsuta, Midori-ku, Yokohama-shi 227
}

\begin{abstract}
The synthesis of $\mathrm{LaCrO}_{3}$ from the mixture of chromium hydroxide and $\mathrm{La}_{2} \mathrm{O}_{3}$ was studied under hydrothermal conditions and in air. $\mathrm{LaCrO}_{3}$ was directly prepared under hydrothermal conditions of above $400^{\circ} \mathrm{C}$ under $100 \mathrm{MPa} \mathrm{H}_{2} \mathrm{O}$ pressure in contrast to the formation of $\mathrm{LaCrO}_{3}$ via $\mathrm{La}_{2} \mathrm{CrO}_{6}$ above $700^{\circ} \mathrm{C}$ in air. $\mathrm{LaCrO}_{3}$ synthesized under hydrothermal conditions was well crystallized with homogeneous grain size of $0.7 \pm 0.2 \mu \mathrm{m}$ at temperatures of $700^{\circ} \sim 1000^{\circ} \mathrm{C}$, while that synthesized in air was an aggregate with irregular grains.
\end{abstract}

[Received April 28, 1981]

\section{水熱条件下における $\mathrm{LaCrO}_{3}$ の合成}

\author{
吉村昌弘・宋 慎 泰*・宗宮重行 \\ (東京工業大学 工業材料研究所)
}

\begin{abstract}
水熱条件下における水酸化クロム水和物と $\mathrm{La}_{2} \mathrm{O}_{3}$ の混合物からの $\mathrm{LaCrO}_{3}$ の合成反忘を調心゙, 空気中に扔ける合成反応と比較した. 水熱条件下では $100 \mathrm{MPa}, 400^{\circ} \mathrm{C}$ 以上で $\mathrm{LaCrO}_{3}$ を直接合 成することができたが，空気中で泜温で中間化合物 $\mathrm{La}_{2} \mathrm{CrO}_{6}$ を生成し， $700^{\circ} \mathrm{C}$ 以上でのみ $\mathrm{LaCrO}_{3}$ の生成が認められた. $700^{\circ} \sim 1000^{\circ} \mathrm{C}$ の水熱条件下で合成された $\mathrm{LaCrO}_{3}$ 生成物は $0.7 \pm$ $0.2 \mu \mathrm{m}$ の均一な微粒子であったが, 空気中で合成された $\mathrm{LaCrO}_{3}$ は大きさ形状ともに不規則な粒 子の集合体であった。

(1981 年 4 月 28 日受付)
\end{abstract}

Key-words : $\mathrm{LaCrO}_{3}$, Hydrothermal synthesis, Fine powder, $\mathrm{La}_{2} \mathrm{CrO}_{6}$

\section{Introduction}

Lanthanum chromite $\mathrm{LaCrO}_{3}$ had been studied earlier from electromagnetic or crystallographic interest ${ }^{1), 2)}$. In recent years, $\mathrm{LaCrO}_{3}$ or doped $\mathrm{LaCrO}_{3}$ have widely been studied as a refractory conducting material because of its electronic conductivity, high melting point $\left(>2400^{\circ} \mathrm{C}\right)$ and oxidation or corrosion resistivity. Particularly, the doped $\mathrm{LaCrO}_{3}$ materials with high electronic conductance have been interested as an electrode for $\mathrm{MHD}^{3), 4)}$, fuel cell ${ }^{5)}$ or electric $\operatorname{arc}^{6)}$, and a heating element ${ }^{7)}$ or a conducting lead for $\mathrm{ZrO}_{2}$-base heating elements ${ }^{8}$. In these studies or applications, $\mathrm{LaCrO}_{3}$ and doped $\mathrm{LaCrO}_{3}$ have generally been synthesized by solid state reac-

* On leave from the Central Iron and Steel Research Institute, Peking, the People's Republic of China tions of oxide mixtures with heating at high temperatures above $1000^{\circ} \mathrm{C}$ in air. These procedures need repeat firing and grinding to complete the reaction due to slow diffusion processes in solids. Therefore we have studied the synthesis of $\mathrm{LaCrO}_{3}$ under hydrothermal conditions in comparison with the usual firing under atmospheric pressure. Here the effects of the temperatures and atmospheres on the synthesis of $\mathrm{LaCrO}_{3}$ is described.

\section{Experimental}

Chromium hydroxide was used as a starting material to improve the reactivity with $\mathrm{La}_{2} \mathrm{O}_{3}$. The chromium hydroxide was precipitated from $3 \mathrm{~N}$ chromic nitrate solution prepared from $\mathrm{Cr}\left(\mathrm{NO}_{3}\right)_{3} \cdot 9 \mathrm{H}_{2} \mathrm{O}$ (guaranteed reagent grade, Kanto Chem. Co., Ltd., Tokyo, Japan) 
by adding into $8 \mathrm{~N} \mathrm{NH}_{4} \mathrm{OH}$ solution. The precipitate was filtered, washed by distilled water thoroughly, then dried at $90^{\circ} \mathrm{C}$ for $24 \mathrm{~h}$ in air. The contents of $\mathrm{Cr}_{2} \mathrm{O}_{3}$ in this hydroxide were analyzed by TG-DTA (Thermoflex TG-DTA, Rigaku Denki Co., Ltd., Tokyo, Japan) and ignition loss measurements. This chromium hydroxide was mixed with lanthanum oxide ( $>99.9 \%$, Shinetsu Chem. Co., Ltd., Japan), of which $\mathrm{La}_{2} \mathrm{O}_{3}$ contents were also analyzed by TG-DTA and ignition loss measurements, to the exact composition of $\mathrm{La}_{2} \mathrm{O}_{3}: \mathrm{Cr}_{2} \mathrm{O}_{3}=1: 1$ (mol) thoroughly in an agate mortar with aceton.

The mixture of about $0.1 \mathrm{~g}$ was sealed with an electric arc in a $\mathrm{Pr}$ capsule $2.7 \mathrm{~mm}$ ID, $0.15 \mathrm{~mm}$ thick and $35 \mathrm{~mm}$ long. The capsule was heated in a test-tube type pressure vessel of Stellite 25 under the pressure of $100 \mathrm{MPa}$ $\mathrm{H}_{2} \mathrm{O}$ at $300^{\circ} \sim 700^{\circ} \mathrm{C}$ for $3 \sim 24 \mathrm{~h}$. The temperature was measured by calibrated Platinel thermocouples attached on the outside wall of the vessel.

In order to study the influences of atmos. pheres, additional experiments were carried out where $\sim 0.06$ g chromium powder ( $>99 \%$, Wako Pure Chem. Co., Ltd., Tokyo) was added on the top of the mixture in the capsule, Chromium would react with $\mathrm{H}_{2} \mathrm{O}$ to produce $\mathrm{Cr}_{2} \mathrm{O}_{3}$ and $\mathrm{H}_{2}$ at high temperatures, so that a reducing atmosphere was created in the capsule.

The synthesis of $\mathrm{LaCrO}_{3}$ from the starting mixture was also studied in air by the TGDTA equipment. The mixture was heated at $600^{\circ} \sim 1200^{\circ} \mathrm{C}$ for $3 \mathrm{~h}$ in a $\mathrm{Pt}$ crucible then cooled rapidly.

All samples prepared were examined by Xray powder diffraction using a diffractometer with a rotating $\mathrm{Cu}$ anode and a graphite monochromater (RU-7, Rigaku Denki Co., Ltd., Japan) and scanning electron microscopy using an equipment (JSM T-200, JEOL Co. Ltd., Japan).

A high purity silicon ( $>99.99 \%$, Kinzoku Kagaku Lab., Tokyo) was added as an internal standard to determine the lattice parameters of $\mathrm{LaCrO}_{3}$.

\section{Results and discussion}

3.1 Characterization of starting materials
The chromium hydroxide prepared was finegrained aggregate as seen in Fig. 1, and amorphous on the basis of the X-ray diffraction. The composition of this material appeared to be $\mathrm{Cr}_{2} \mathrm{O}_{3} \cdot 6.42 \mathrm{H}_{2} \mathrm{O}$ from the ignition loss measurements. Based upon the X-ray diffraction, small amount of $\mathrm{La}(\mathrm{OH})_{3}$ was detected in used $\mathrm{La}_{2} \mathrm{O}_{3}$ (Fig. 2). The water contents of this material was determined to be $\mathrm{La}_{2} \mathrm{O}_{3} \cdot 0.95 \mathrm{H}_{2} \mathrm{O}$ by ignition loss measurements and TG-DTA. Table 1 summarizes the characterization of the starting materials.

\subsection{Synthesis of $\mathrm{LaCrO}_{3}$ under hydrothermall conditions}

Table 2 shows the results of hydrothemal experiments. The product heated at $300^{\circ} \mathrm{C}$ was identified to be crystallized $\mathrm{La}(\mathrm{OH})_{3}$ and small amount of $\mathrm{LaCO}_{3} \mathrm{OH}^{9}$ by X-ray diff-

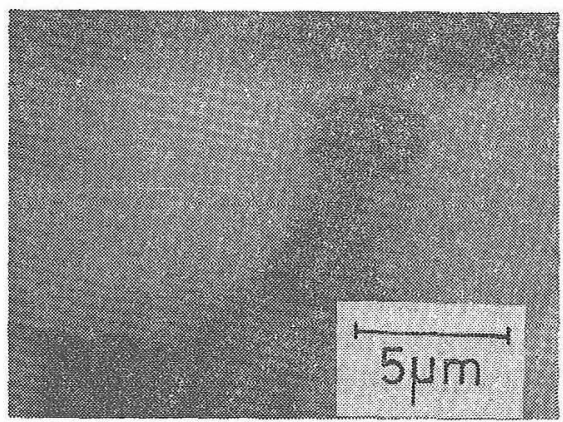

Fig. 1. SEM photograph of prepared chromium hydroxide.

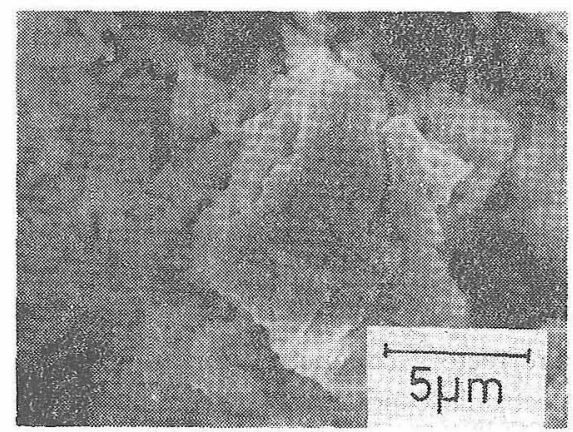

Fig. 2. SEM photograph of lanthanum oxide.

Table 1. Characterization of starting materials.

\begin{tabular}{|c|c|c|}
\hline Material & $x$-ray analysis & $\begin{array}{l}\text { Water contents } \\
\mathrm{n} \text { values in } \mathrm{M}_{2} \mathrm{O}_{3} \cdot \mathrm{nH}_{2} \mathrm{O}\end{array}$ \\
\hline Chromiun hydroxide & Amorphous & 6.42 \\
\hline Lanthanum oxide & $\mathrm{La}_{2} \mathrm{O}_{3}+\mathrm{La}(\mathrm{OH}\}_{3}^{*}$ & 0.95 \\
\hline
\end{tabular}


raction (Fig. 3). Chromium hydroxide might exist still in amorphous state because no crystallized chromium compounds could be detected in this product. The formation of $\mathrm{LaCO}_{3} \mathrm{OH}$ indicates the contamination of starting $\mathrm{La}_{2} \mathrm{O}_{3}$ by $\mathrm{CO}_{2}$ gas absorbed from atmosphere. Similar phenomena have often been observed in the studies in the system $\mathrm{La}_{2} \mathrm{O}_{3}-\mathrm{H}_{2} \mathrm{O}$ under hydrothermal conditio$\mathrm{ns}^{10), 11)}$. The crystal $\mathrm{LaCO}_{3} \mathrm{OH}$ is significantly stable under hydrothermal conditions particularly high pressures as $100 \mathrm{MPa}$ or above $^{(0)}$ in the presence of $\mathrm{CO}_{2}$ components, even they were in a small amount, in the system. $\mathrm{LaCO}_{3} \mathrm{OH}$ remained at $500^{\circ} \mathrm{C}$ and traced at $600^{\circ} \mathrm{C}$, but has not been detected above $700^{\circ} \mathrm{C}$. The product of $400^{\circ} \mathrm{C}$ was almost well crystallized $\mathrm{LaCrO}_{3}$ indicating the reaction between $\mathrm{La}(\mathrm{OH})_{3}$ and chromium hydroxide with the release of $\mathrm{H}_{2} \mathrm{O}$. Scanning

Table 2. X-ray diffraction analysis of the products prepared hydrothermally under 100 $\mathrm{MPa}$.

\begin{tabular}{|c|c|c|}
\hline Terperature $\left({ }^{\circ} \mathrm{C}\right)$ & Perios (hr) & Identified phases \\
\hline 300 & 3 & $\mathrm{La}(\mathrm{CH})_{3}(\mathrm{vs}), \mathrm{LaCO}_{3} \mathrm{OH}(\mathrm{w})$ \\
\hline 400 & 3 & $\mathrm{LaCrO}_{3}$ (vs), $\mathrm{LaCO}_{3} \mathrm{OH}(\mathrm{w})$ \\
\hline 400 & 24 & $\mathrm{LaCrO}_{3}$ (vs), $\mathrm{LaCO}_{3} \mathrm{OH}(\mathrm{w})$ \\
\hline 500 & 3 & $\mathrm{LaCrO}_{3}$ (vs), $\mathrm{LaCO}_{3} \mathrm{OH}(\mathrm{ve})$ \\
\hline 600 & 3 & $\mathrm{LaCrO}_{3}$ (vs), $\mathrm{LaCO}_{3} \mathrm{OH}(\mathrm{tr})$ \\
\hline 700 & 3 & $\mathrm{LaCrO}_{3}$ (vs) \\
\hline
\end{tabular}

vs-very strong, w-weak, ww-very weak, tr-trace

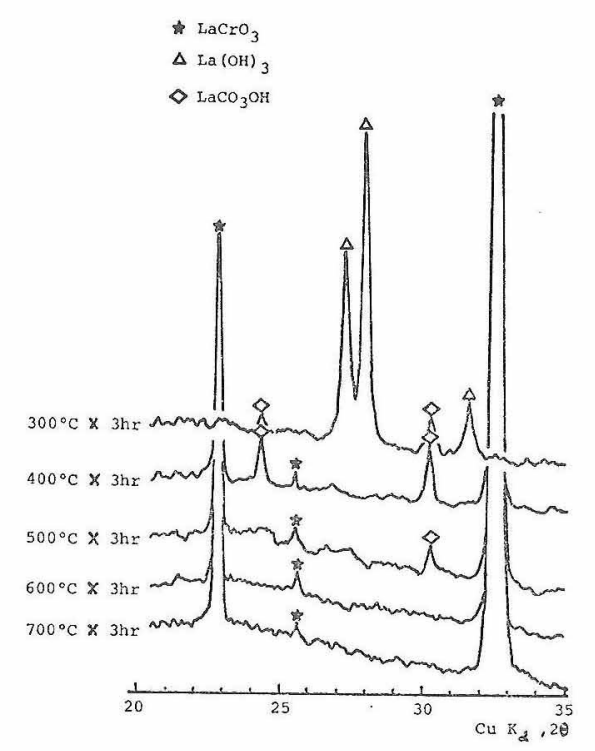

Fig. 3. X-ray powder pattern of the products prepared under hydrothermal conditions. electron photomicrograph of this product (Fig. 4) revealed fine-grained $\mathrm{LaCrO}_{3}$ of about $0.1 \mu \mathrm{m}$ in diameter and hydrothermally grown $\mathrm{LaCO}_{3} \mathrm{OH}$ crystals of $1 \sim 3 \mu \mathrm{m}$ in edge. As the reaction temperature elevated, the amount and the size of $\mathrm{LaCO}_{3} \mathrm{OH}$ crystals decreased while the production of $\mathrm{LaCrO}_{3}$ increased. Only well crystallized $\mathrm{LaCrO}_{3}$ could be observed in the product at $700^{\circ} \mathrm{C}$. The $\mathrm{LaCrO}_{3}$ crystals has homogeneous grain size of $0.7 \pm 0.2 \mu \mathrm{m}$ (Fig. 5). The hydrothermally prepared $\mathrm{LaCrO}_{3}$ has an orthorhombic symmetry (Pbnm) with the lattice parameters $a=5.477 \AA, b=5.511 \AA$ and $c=$ $7.758 \AA$, which are in good agreement with the previous data ${ }^{2), 12) \sim 14)}, a=5.476 \sim 5.479 \AA$, $b=5.512 \sim 5.515 \AA$ and $c=7.752 \sim 7.758 \AA$ for pure $\mathrm{LaCrO}_{3}$ prepared in air at high temperatures above $1000^{\circ} \mathrm{C}$. These results indicate that formation of $\mathrm{LaCrO}_{3}$ has been completed in a short period of $3 \mathrm{~h}$ at temperatures as low as $700^{\circ} \mathrm{C}$ under hydrothermal conditions due to the action of supercritical water as a mineralizer.

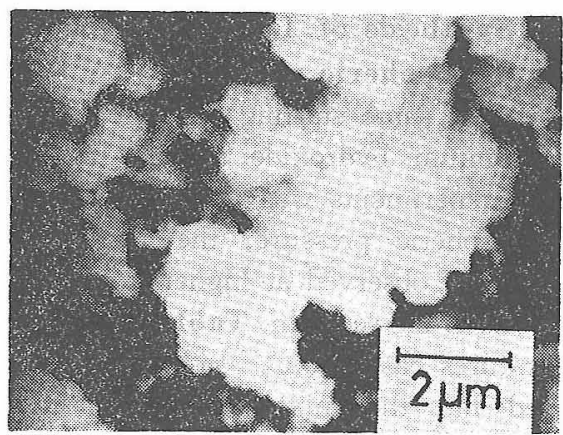

Fig. 4. SEM photograph of the product prepared under hydrothermal condition (at $400^{\circ} \mathrm{C}, 100 \mathrm{MPa}$, for $3 \mathrm{~h}$ ).

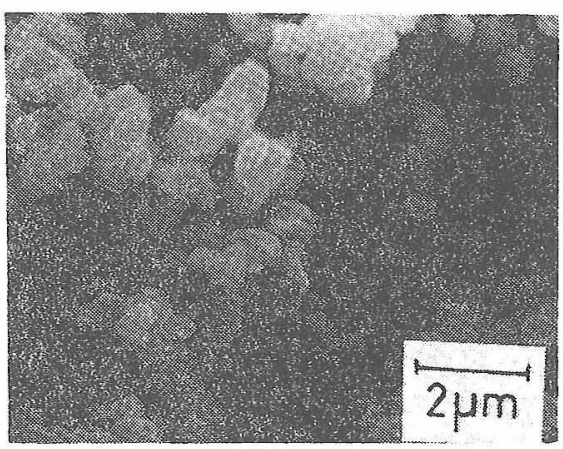

Fig. 5. SEM photograph of the product prepared under hydrothermal condition (at $700^{\circ} \mathrm{C}, 100 \mathrm{MPa}$, for $3 \mathrm{~h}$ ). 
In the experiments with $\mathrm{Cr}$ powder, $\mathrm{LaCrO}_{3}$ was also synthesized in the capsule at temperatures above $400^{\circ} \mathrm{C}$. The products in the experiments with $\mathrm{Cr}$ powder were entirely identical with those in the experiments without $\mathrm{Cr}$ powder. A reducing atmosphere created by the hydrogen produced by the reaction

$$
2 \mathrm{Cr}+3 \mathrm{H}_{2} \mathrm{O} \rightarrow \mathrm{Cr}_{2} \mathrm{O}_{3}+3 \mathrm{H}_{2}
$$

at temperatures above $600^{\circ} \mathrm{C}^{15)}$, had little effect on the formation of $\mathrm{LaCrO}_{3}$. These results indicate that $\mathrm{LaCrO}_{3}$ is stable under a reducing conditions, though oxygen deficient $\mathrm{Ca}$-doped $\mathrm{LaCrO}_{3}$ has been prepared ${ }^{16)}$ under a similar hydrothermal conditions employed in the present study. The water was decomposed into hydrogen which could permeate through the wall of the $\mathrm{Pt}$ capsule at high temperatures, so that a weight loss could be observed after hydrothermal treatments. The elimination of water contents, $12 \%$ or $18 \%$ at $600^{\circ} \mathrm{C}$, corresponding to the observed weight losses did also show no significant effects on the formation and the crystal growth of $\mathrm{LaCrO}_{3}$.

\subsection{Synthesis of $\mathrm{LaCrO}_{3}$ in an atmospheric pressure}

When the same starting mixture of $\mathrm{La}_{2} \mathrm{O}_{3}$ and chromium hydroxide as that in hydrothermal experiments was heated in air with an atmospheric pressure, the formation of $\mathrm{LaCrO}_{3}$ was observed at higher temperatures above $700^{\circ} \mathrm{C}$ as seen in Table 3. At lower temperatures as $600^{\circ} \mathrm{C}$, no $\mathrm{LaCrO}_{3}$ was detected but the mixture of $\mathrm{La}_{2} \mathrm{CrO}_{6}$ and small amounts of $\mathrm{La}_{2} \mathrm{O}_{3}$ and $\mathrm{Cr}_{2} \mathrm{O}_{3}$. According to the results by TG-DTA and $\mathrm{X}$-ray diffraction for the samples heated at various temperatures, the reaction process to form $\mathrm{LaCrO}_{3}$ in air appeared to be as follows,

Table 3. X-ray diffraction analysis of the products prepared in air $(0.1 \mathrm{MPa})$.

\begin{tabular}{|c|c|c|}
\hline Temperature $\left({ }^{\circ} \mathrm{C}\right)$ & Pericd $(h x)$ & Icentified phases \\
\hline $300^{\circ} \mathrm{C}$ & 3 & $\mathrm{Ia}_{2} \mathrm{O}_{3}(\mathrm{vs}), \mathrm{Ia}(\mathrm{OH})_{3}(\mathrm{~g})$ \\
\hline $400^{\circ} \mathrm{C}$ & 3 & $\mathrm{La}_{2} \mathrm{O}_{3}$ (vs), $\mathrm{IaCOH}(\mathrm{s}), \mathrm{Cr}_{2} \mathrm{O}_{3}$ (vs) \\
\hline $500^{\circ} \mathrm{C}$ & 3 & $\mathrm{Ia}_{2} \mathrm{O}_{3}$ (vs), IaCOH (w), $\mathrm{Cr}_{2} \mathrm{O}_{3}$ (vs) \\
\hline $550^{\circ} \mathrm{C}$ & 3 & $\mathrm{In}_{2} \mathrm{O}_{3}$ (vs), $\mathrm{Cr}_{2} \mathrm{O}_{3}$ (vs) \\
\hline $600^{\circ} \mathrm{C}$ & 3 & $\mathrm{Ia}_{2} \mathrm{CrO}_{6}(\mathrm{vs}), \mathrm{Ia}_{2} \mathrm{O}_{3}(\mathrm{~m}), \mathrm{Cr}_{2} \mathrm{O}_{3}(\mathrm{~m})$ \\
\hline $700^{\circ} \mathrm{O}$ & 3 & $\mathrm{LaCrO}(\mathrm{vs}), \mathrm{Ia}_{2} \mathrm{CrO}_{6}(\mathrm{w}), \mathrm{La}_{2} \mathrm{O}_{3}(\mathrm{vw}), \mathrm{Cr}_{2} \mathrm{O}_{3}(\mathrm{~m})$ \\
\hline $800^{\circ} \mathrm{C}$ & 3 & $\mathrm{LaCrO}_{3}(v s), \mathrm{La} 2 \mathrm{CrO}_{6}(\mathrm{wu})$ \\
\hline $900^{\circ} \mathrm{C}$ & 3 & $\mathrm{LaCrO}_{3}(\vartheta \mathrm{G})$ \\
\hline $1200^{\circ} \mathrm{C}$ & 3 & $\mathrm{~L}=\mathrm{CrO}_{3}$ (vs) \\
\hline
\end{tabular}

vs-very strong,s-strong, i-weak, wi-very weak

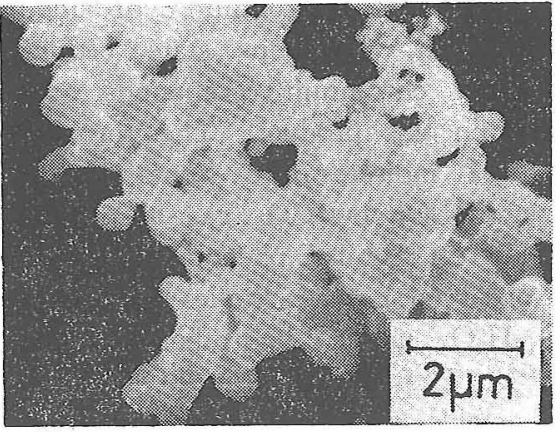

Fig. 6. SEM photograph of the product prepared in air (at $1200^{\circ} \mathrm{C}, 0.1 \mathrm{MPa}$, for $3 \mathrm{~h})$.

$\mathrm{La}_{2} \mathrm{O}_{3}$ containing $\mathrm{La}(\mathrm{OH})_{3}+\mathrm{Cr}$ hydroxide $\stackrel{\sim 440^{\circ} \mathrm{C}}{\longrightarrow} \mathrm{La}_{2} \mathrm{O}_{3}$ containing $\mathrm{LaOOH}+\mathrm{Cr}_{2} \mathrm{O}_{3}$ $\stackrel{\sim 550^{\circ} \mathrm{C}}{\longrightarrow} \mathrm{La}_{2} \mathrm{O}_{3}+\mathrm{Cr}_{2} \mathrm{O}_{3} \stackrel{>600^{\circ} \mathrm{C}}{\longrightarrow} \mathrm{La}_{2} \mathrm{CrO}_{6}+$ $\mathrm{Cr}_{2} \mathrm{O}_{3} \stackrel{>900^{\circ} \mathrm{C}}{\longrightarrow} \mathrm{LaCrO}_{3}$

The formation of $\mathrm{La}_{2} \mathrm{CrO}_{6}$ with the oxidation of chromic oxide is characteristic ${ }^{17}$ in the reaction between $\mathrm{La}_{2} \mathrm{O}_{3}$ and $\mathrm{Cr}_{2} \mathrm{O}_{3}$ in air. The powder of $\mathrm{LaCrO}_{3}$ prepared in air at temperatures above $900^{\circ} \mathrm{C}$ aggregated irregularly as shown in Fig. 6 .

\section{Summary}

Pure $\mathrm{LaCrO}_{3}$ was synthesized at low temperatures as $700^{\circ} \mathrm{C}$ under hydrothermal conditions with $100 \mathrm{MPa}$ pressure for $3 \mathrm{~h}$ from $\mathrm{La}_{2} \mathrm{O}_{3}$ and chromium hydroxide. $\mathrm{LaCrO}_{3}$ was well crystallized with homogeneous grain size of $0.7 \pm 0.2 \mu \mathrm{m}$. The water seemed to accelerate the reaction between $\mathrm{La}_{2} \mathrm{O}_{3}$ or $\mathrm{La}$ hydroxide and $\mathrm{Cr}_{2} \mathrm{O}_{3}$ or $\mathrm{Cr}$ hydroxide as a mineralizer. The formation process under hydrothermal conditions appears to be simpler than that via the formation of $\mathrm{La}_{2} \mathrm{CrO}_{5}$ as an intermediate compound in air.

\section{References}

1) I. Náray-Szabó, Muegyetemi Kozlemenyek, 1, 30 (1974).

2) S. Geller, Acta Cryst., 10, 243 (1957).

3) A.M. Anthony, G. Benezech, F. Cabannes, M. Faucher, M. Foex, Vutien Loc and D. Yerouchalmi, Proc. of the IUPAC 3 rd Int. Symp. on High Temperature Technology, 213-33, Butterworths, London, 1969.

4) D.B. Meadowcroft, P.G. Meier and A.C. Warren, Energy Conversion, 12, 145 (1972).

5) H. Kleinschmager and A. Reich, Z. Naturforsch., 27, 363 (1972).

6) S. Kose, Kagaku Kogyo, 72 (1974).

7) S. Kose, Shinkinzoku Kogyo, 1873, 265-70. 
8) S.T. Song, H.Y. Pan, J.R. Feng and Z. Wang, J. Chinese Silicate Soc., 7, 238-43 (1979).

9) B.H.T. Chai and S. Mroczkowski, J. Cryst. Growth, 44, 84-97 (1978).

10) M.W. Shafer and R. Roy, J. Am. Ceram. Soc., 42, 564 (1959).

11) T.R. Narayanan Kutty, M.N. Viswanathiah and J.A.K. Tareen, Proc. Indian Acad. Sci., 87 A, 69 -74 (1978).

12) C.E. Gooden and G.J. McCarthy, Powder Diffraction File 24-1016, Joint Committee on Powder Diffraction Standard USA (1974).

13) C.P. Khattak and D.E. Cox, Mater. Res. Bull., 12, 463 (1977).

14) J. Faber, Jr., M.H. Muller, W.L. Procarione,
A.T. Aldred, H.W. Knott and H.U. Anderson, Proc. of Conf. on High Temperature Sciences Related to Open-Cyclet Coal Fired MHD Systems, Argonne, Illinois, 1977, CONF-770411-1, Government Reports Announcements, vol. 77, No. 26, $11 \mathrm{~B}$.

15) S. Sōmiya, M. Yoshimura and H. Kanai, to be published in Zairyokagaku (J. of the Mater. Sci. Soc. of Japan).

16) S.T. Song, M. Yoshimura and S. Sõmiya, to be published in Zairyokagaku (J. of the Mater. Sci. Soc. of Japan).

17) R. Berjoan, G. Benezech, J-P. Coutures and M. Foex, C.R. Acad. Sci. Paris, 280 C, 601-03 (1975).

実験・技術・調查報告・Report

\title{
マグネシア質断熱耐火物の試作 (マグネシア多泡粒の研究, その 2)
}

\author{
本江秋弘・和波達夫*・石堂普彦 \\ 移年川卓哉*・長田 清・藤井欽二郎

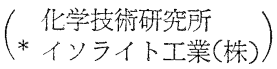

酶酸液滴からのマグネシアまたはマグネシアークロム鉄鉱多泡粒を用いて断熱耐火煉瓦を調製す ることができる．すなわち，バルクな多泡粒を水で湿らすと，若干可塑性が現れて加圧成形を容易 にし, 乾燥するとかなりの強度を発生, 高温焼成すれば, 比較的小さな焼成収縮で軽量なマグネシ アまたはマグネシアークロム鉄鉱系多孔質煉瓦が得られる.

本実験に用いた多泡粒は， $0.42 \sim 1.7 \mathrm{~mm}$ 粒分 $30 \mathrm{wt} \%$ 1.7 3.3 mm 粒分 $50 \mathrm{wt} \%$ また 3.3 $\sim 4.7 \mathrm{~mm}$ 粒分 $20 \mathrm{wt} \%$ の粒度分布をむち, 成形に好ましい水分量は, 成形圧 $10 \mathrm{~kg} / \mathrm{cm}^{2}$ の場合, 約 $5 \mathrm{wt} \%$ であった. $105^{\circ} \mathrm{C}$ で乾燥した成形体の圧縮強さは $27 \mathrm{~kg} / \mathrm{cm}^{2}$ である. 加熱すると, 約 $300^{\circ} \mathrm{C}$ で酢酸塩が分解してアセトンと炭酸ガスを発生し, 続いて $1500^{\circ} \mathrm{C}$ 加熱で線収縮 $4.5 \%$, 圧縮 強さ $50 \mathrm{~kg} / \mathrm{cm}^{2}$ の軽量獟成体 (かさ比重, $1.2 \mathrm{~g} / \mathrm{cm}^{3}$ ) を得た。熱伝導率は $1000^{\circ} \mathrm{C}$ で, $0.95 \mathrm{kcal} /$ $\mathrm{m} \cdot \mathrm{h} \cdot{ }^{\circ} \mathrm{C}$, これは普通のマグネシア煉瓦の約 $1 / 4$ である. 平炉及び転炉スラグの浸食性を調べたと ころ焼成体組織へわずかに浸透したものの良い耐食性を示した。

(1981 年 5 月 8 日受付)

\section{Trial Preparation of Heat Insulating Magnesia Refractories (Study on Porous Magnesia Grains, Part 2)}

\author{
Akihiro MOTOE, Tatsuo WANAMI*, Yoshihiko ISHIDO, \\ Takuya MASUKAWA*, Kiyoshi OSADA and Kinjiro FUJII \\ $\left(\begin{array}{l}\text { National Chemical Laboratory for Industry } \\ \text { 1-1, Yatabemachi-higashi, Tsukuba-gun Ibaraki 305 } \\ \text { * Isolite Insulating Products Co., Ltd. }\end{array}\right.$
}

A heat insulating fire brick made of magnesia or magnesia-chromite mixture can successfully be produced from the respective porous grains prepared by use of acetic acid droplets 